\title{
The influence of TLR4 gene polymorphisms on milk quality and composition of Lithuanian Holstein cows
}

\author{
Ramutè Mišeikiené, Agnieté Švedaité, Renata Bižienè, \\ Nijolè Pečiulaitienè, Rasa Ugenskiené
}

\begin{abstract}
Lithuanian University of Health Sciences, Veterinary Academy, Faculty of Animal Science, Institute of Biology Systems and Genetic Research, Tilžès 18, Kaunas, Lithuania

${ }^{*}$ Corresponding author: E-mail: ramute.miseikiene@Ismuni.lt
\end{abstract}

\section{Abstract}

This study investigated bovine TRL4 gene c.9421C>T, c.2021C>T and c.-10C>T polymorphisms and their relationship with somatic cell count and indicators of milk composition. Blood samples were collected from 152 Lithuanian Holstein dairy cows. The method of polymerase chain reaction (PCR) and restriction fragment length polymorphism (RFLP) was used to genotype TLR4 gene polymorphisms. The data concerning somatic cell count and milk composition indicators (fat, protein, lactose) were analysed. The influence of genes and statistical significance of differences between different genotypes was evaluated by the one-factor dispersion analysis (ANOVA). Results showed that c.9421C>T was significantly associated with somatic cell count in milk. Also a significant association between the genotypes of c.9421C>T and somatic cell count was found $(\mathrm{P}<0.05)$. Cattle with the TT genotype showed the lowest somatic cell count. TLR4 gene polymorphisms C.2021C>T and c.-10C>T have no significant effect on mastitis resistance and milk composition. Analysis of the combined genotypes TC/CC of c.2021C>T and c.9421C>T allowed us to determine the possible association of SNPs with the somatic cell count and lactose content. The study showed a significant association between the somatic cell count (SCC) and TLR4 polymorphism c.9421C>T in Lithuanian Holstein cows. SCS of cows with a TT genotype was significantly lower and indicated the association of TT genotype with resistance to mastitis in c.9421 C>T and allele T might be the beneficial allele for mastitis resistance.

Key words: Lithuanian Holstein cow, milk, single nucleotide polymorphisms, toll-like receptor 4

\section{Introduction}

Mastitis is one of the most prevalent diseases of dairy cattle, which causes huge economic losses to the dairy industry worldwide (Ruegg, 2003). The somatic cell count (SCC) in milk is regarded to reflect the degree of mastitis. The mammary gland tissue is protected by two defence systems of the immune system: innate or nonspecific immunity and the acquired or specific immunity. Both, innate and acquired immunity, interact in the attempt to provide protection against mastitis causing microorganisms (Burvenich et al., 2015). Quantitative trait loci (QTL) for mastitis and SCC have been identified in nearly all chromosomes of the bovine genome (Rupp et al., 2015). Ten different TLRs (TLR1 to TLR10) have been identified in cattle. Among them, TLR2, TLR4, TLR6 and TLR9 genes have been found associated with mastitis resistance in cattle and play a role in innate immunity (Yang et al., 2008). 
The genes that are strong potential markers for resistance/susceptibility to udder inflammation include genes encoding PAMP-recognition receptors (PRRs) (Sharma et al., 2006). TLR4 is a candidate gene for resistance to a large number of diseases. Toll-like receptor 4 (TLR4) recognizes pathogen ligands and mediates signalling to initiate innate and adaptive immune responses (Wang et al., 2007). TLR4 was the first mammalian TLR identified, and it is consequently the best described of the family (Takeda et al., 2003). The structure of bovine TLR4 gene is very complex. This gene encodes 841 amino acids (Wang et al., 2007; El-Domany et al., 2019). The TLR4 gene in cattle about 3739-bp, contains an open reading frame of 2526-bp encoded 841 amino acids (El-Domany et al., 2019). The bovine TLR4 gene coding region is 2526 bp long, consists of 3 exons and is located on chromosome BTA 8 (White et al., 2003). Bovine TLR4 is highly polymorphic with more than 40 SNPs (single nucleotide polymorphisms) of the bovine TLR4 gene have been found to date, which means an average of 1 SNP per 90 bp (Wang et al., 2007). TLR4 gene discovered across 14 breeds of cattle (Sharma et al., 2006; Wang et al., 2007; Opsal et al., 2008).

There are several studies reporting associations between TLR4 polymorphism and milk traits in dairy cows. Beecher et al. (2010) revealed an association between variation in TLR4 and milk fat and protein percentage in late lactation in Irish cattle. In Iranian Holstein cattle No ori et al. (2013) described an association between TLR4 exon 3 variation, and somatic cell score and milk-related traits (305-day milk yield, breeding value for milk yield and lower fat percentage), while Zhou et al. (2017) have described how polymorphisms of the TLR4 gene influences milk production traits in Chinese Holstein cows. Sharma et al. (2006) described an association between TLR4 and lactation persistency in Canadian dairy cattle, while in Irish cattle Beecher et al. (2010) found an association between variation in TLR4 and milk fat and protein percentage. In Iranian Holstein cattle No ori et al. (2013) described an association between TLR4 exon 3 variation, and somatic cell score and milk-related traits, while Zhou et al. (2017) have determined how polymorphisms of the TLR4 gene influences milk fat content in Chinese Holstein cows. Based on the findings of Ogorevc et al. (2009) who examined the role of TLR4 in pathogen recognition and subsequent initiation of the inflammatory and immune response, and on differential expression of the gene during mastitis, TLR4 has been proposed as a candidate for increasing mastitis resistance in breeding programs.

The purpose of our research was to investigate TRL4 c.9421C>T, c.2021C>T and c.-10C>T polymorphisms and to evaluate their correlation with somatic cell count and milk productivity traits in Lithuanian Holstein cows.

\section{Materials and methods}

\section{Sample collection and DNA extraction}

Blood samples were collected from 152 Lithuanian Holstein dairy cows. $5 \mathrm{~mL}$ of blood was collected from each animal jugular vein in tubes containing $2.7 \%$ EDTA and stored at $-20{ }^{\circ} \mathrm{C}$. Analyses were done in Lithuanian University of Health Sciences, Dr. K. Janušauskas Laboratory of Genetic (Kaunas, Lithuania). Genomic DNA was isolated from cows' blood using the GeneJET Genomic DNA Purification Kit (Thermo Fisher Scientific, Waltham, MA, USA) following the recommended protocols. Primers applied for genotyping are shown in Table 1.

TABLE 1. TLR4 gene polymorphisms and oligonucleotide primers

\begin{tabular}{l|l|l|l|l|l}
\hline SNP & Primers sequence (5-3') & $\begin{array}{l}\text { Restriction } \\
\text { enzyme }\end{array}$ & Position & $\begin{array}{l}\text { Amplicon } \\
\text { size, bp }\end{array}$ & $\begin{array}{l}\text { fragment } \\
\text { size, bp }\end{array}$ \\
\hline c.9421 C>T & $\begin{array}{l}\text { AGACAGCATTTCACTCCCTC } \\
\text { ACCACCGACACACTGATGAT }\end{array}$ & Alul & $\begin{array}{l}\text { Partial } \\
\text { exon3 }\end{array}$ & 382 & $118,142^{*}$ \\
\hline c.2021 C>T & $\begin{array}{l}\text { GGGTCCTAGTCTACAAGTTC } \\
\text { ACGATGAAGATGATGCCAG }\end{array}$ & BsiHKAl & $\begin{array}{l}\text { Partial } \\
\text { exon3 }\end{array}$ & 367 & 75,292 \\
\hline c.10 C>T & $\begin{array}{l}\text { CGTAACCCAGCACTCCTTTC } \\
\text { GCCTGTTAATGCCCTGTAACC }\end{array}$ & BstUI & $\begin{array}{l}\text { Partial } \\
\text { exon3 }\end{array}$ & 405 & 159,246 \\
\hline
\end{tabular}

*77, 32 and 13 bp in agarose gel is not visible 


\section{PCR and polymorphism detection}

Primers for 3 SNPs in TLR4 (c.9421C>T, c.2021C>T and c.-10C>T) T4CRBR2, rs8193069, rs8193041) gene were designed (NCBI Reference sequence: NC_037335.1). The method of polymerase chain reaction (PCR) and restriction fragment length polymorphism (RFLP) was used to genotype TLR4 gene polymorphisms. The PCR reactions for c.2021C>T and c.-10C>T were performed in 25 $\mu \mathrm{L}$ volume of reaction mixture containing $15.0 \mu \mathrm{L}$ MasterMix (Thermo Fisher Scientific, Waltham, MA, USA), $0.5 \mu \mathrm{M}$ (10 pmoL) of each primer pair (Table 1) using Applied Biosystems 2700 Thermal Cycler (Applied Biosystems, Foster City, CA, USA), $2 \mu \mathrm{L}$ (50 ng) genomic DNA and 7.0 Nuclease-free water. The PCR mixture for C.9421C>T contained $1.5 \mu \mathrm{L}$
(50 ng) DNA, $0.4 \mu \mathrm{L}$ (10 pmoL) of each primer, 2 $\mu \mathrm{L}$ 10x PCR buffer, $(0.4 \mu \mathrm{L}) 200 \mu \mathrm{mol}$ dNTPs and $5 \mathrm{U}$ of Taq DNA polymerase in a total volume of $20 \mu \mathrm{L}$. The primers and optimal conditions of PCR of TLR4 SNP's are presented in Table 1 and Table 2. After amplification, $10 \mu \mathrm{L}$ of PCR product were digested with a selected restriction enzyme (Table 1) according to producer recommendations (Thermo Fisher Scientific, Waltham, MA, USA). The visualization of the different genetic types was carried out by the $2 \%$ agarose gel electrophoresis. The ethidium bromide was added to agarose to a final concentration of $0.5 \mu \mathrm{g} / \mathrm{mL}$ (Thermo Fisher Scientific, Waltham, MA, USA). Fragment identification was performed in ultraviolet light, using MiniBIS Pro Video Documentation System (DNR Bio-Imaging System, Neve Yamin, Israel).

TABLE 2. TLR4 gene polymorphisms reaction conditions

\begin{tabular}{l|l|l|l|l|l|l}
\hline SNP & Predegeneration & Generation & Annealing & Extension & Cycle & Extension \\
\hline $\mathrm{C} .9421 \mathrm{C}>\mathrm{T}$ & $95^{\circ} \mathrm{C} 5 \mathrm{~min}$ & $94^{\circ} \mathrm{C} 30 \mathrm{~s}$ & $62{ }^{\circ} \mathrm{C} 30 \mathrm{~s}$ & $72{ }^{\circ} \mathrm{C} 40 \mathrm{~s}$ & 35 & $72{ }^{\circ} \mathrm{C} 40 \mathrm{~s}$ \\
\hline $\begin{array}{l}\text { C. } 2021 \mathrm{C}>\mathrm{T} \\
\text { C. }-10 \mathrm{C}>\mathrm{T}\end{array}$ & $94^{\circ} \mathrm{C} 4 \mathrm{~min}$ & $94^{\circ} \mathrm{C} 30 \mathrm{~s}$ & $53.9{ }^{\circ} \mathrm{C} 30 \mathrm{~s}$ & $72{ }^{\circ} \mathrm{C} 30 \mathrm{~s}$ & 35 & $72{ }^{\circ} \mathrm{C} 10 \mathrm{~min}$ \\
\hline
\end{tabular}

\section{Traits and statistical analysis}

Genetic parameters for milk quality (somatic cell count, thousand/ml) and milk composition (fat, protein and lactose percentage) in Lithuanian Holstein population were estimated.

The data concerning SCC and milk composition indicators were derived from the results of monthly test milkings. Fat, protein and lactose content was determined by the infrared instrument LactoScope FTIR (Perten Instruments, Stockholm, Sweeden). Somatic cell count was performed by the heavy-duty counter-measurer Somascope (Perten Instruments, Stockholm, Sweeden) which operates by the fluoro-opto electronic method. Milk analysis was performed at State Enterprise "Pieno Tyrimai" in an accredited central milk testing laboratory in Lithuania.

The analysis was performed using data accumulation and analysis program SPSS 22.0 (Statistical Package for Social Science 22 for Windows). The following descriptive statistics were used for the exploratory characteristics: arithmetic mean and its error; frequency distributions for qualitative variables were calculated genotype and allele frequencies for the studied population of cows. Using the one-factor dispersion analysis (ANOVA, post-hoc Fisher LSD criterion, $a=0.05$ ) influence of genes and statistical significance of differences between different genotypes were evaluated. The results are considered reliable when $\mathrm{P}<0.05$. Using the Kolmogorov-Smirnov test the assumption of the continuity of the variables was verified.

\section{Results}

Allele $C$ was detected in 77 heterozygous and 43 homozygous samples out of 152 samples for the c.9421 C > T. After carrying out genotyping allele T was detected in 145 heterozygous and 5 homozygous samples out of 152 samples at the c.2021C>T. Meanwhile, allele $C$ was detected in 1 heterozygous and 151 homozygous samples at the c.-10C>T polymorphism. 
The genotypic and allelic frequencies are shown in Table 3. In two polymorphisms - c.9421 C>T and c.2021 C>T all three possible genotypes (TT, TC and CC) were identified. The most equal distribution of genotypes established at c.9421C>T, which means that this polymorphism is evenly distributed among dairy cattle. Genotype TC was the most common genotype in two c.9421C>T and c.2021C>T polymorphisms though allele $T$ was more frequent in c.9421C>. TC frequency was $44.7 \%$ bigger in c.2021C>T than in c.9421C>T. TT genotypic frequency was the least (3.3\%) in the c.2021C>T. Both alleles ( $T$ and $C$ ) and two genotypes (TC and CC) with very uneven distribution were observed in c.-10C $>T$. The TT genotype was not detected in cows may be due to the insufficient number of cows.

TABLE 3. Allele and genotype frequency of the TLR4 SNP's in Lithuanian Holstein cows

\begin{tabular}{|c|c|c|c|c|c|}
\hline SNP & Genotype & Number of cows & Genotype frequency & Allele & Allele frequency \\
\hline \multirow[t]{3}{*}{ c.9421 C>T } & CC & 43 & 0.283 & $C$ & 0.536 \\
\hline & $T C$ & 77 & 0.507 & $T$ & 0.464 \\
\hline & TT & 32 & 0.210 & - & - \\
\hline \multirow[t]{3}{*}{ c.2021 C>T } & CC & 2 & 0.013 & C & 0.490 \\
\hline & $T C$ & 145 & 0.954 & $T$ & 0.510 \\
\hline & TT & 5 & 0.033 & - & - \\
\hline \multirow[t]{3}{*}{ c. -10 C>T } & $C C$ & 151 & 0.993 & C & 0.997 \\
\hline & $T C$ & 1 & 0.007 & $T$ & 0.003 \\
\hline & TT & 0 & 0 & - & 0 \\
\hline
\end{tabular}

The association of TLR4 gene SNP's with somatic cell count was analysed (Table 4). A significant association between the genotypes of c.9421C>T and SCC was found $(P<0.05)$. Cattle with the TT genotype showed the lowest SCC in comparison to the cattle with TC genotype. A non-significant association between the genotypes TC and CC of C.-10C>T was found, but SCC in cattle with TC genotype was on average 209.0 thousand/ $\mathrm{mL}$ lower by following with CC genotype. Cows with CC genotype had the biggest influence on SCC in c.2021C>T.

The results of TLR4 SNP's on milk production traits presented in Table 5. Results showed that genotypes of two SNP's (c.9421C>T and c.2021C>T) had an influence on milk fat and protein percentage although no significant associations between these genotypes have been established. Genotype TC of c.9421C>T showed higher fat and protein percentage than the other two genotypes while the highest lactose percentage
TABLE 4. Effects of different polymorphisms genotypes on somatic cell count

\begin{tabular}{l|l|l}
\hline SNP & Genotype & $\begin{array}{l}\text { SCC thousand } / \mathrm{mL} \\
\text { (mean } \pm \text { SE) }\end{array}$ \\
\hline \multirow{2}{*}{ C.9421 C>T } & CC & $309.35 \pm 43.33$ \\
\cline { 2 - 3 } & TC & $362.51 \pm 48.57^{\mathrm{a}}$ \\
\cline { 2 - 3 } C.2021 C>T & TT & $176.47 \pm 21.92^{\mathrm{b}}$ \\
\hline \multirow{2}{*}{ C.10 C>T } & TC & $121.5 \pm 82.5$ \\
\cline { 2 - 3 } & TT & $289.2 \pm 84.55$ \\
\cline { 2 - 3 } & CC & $309.68 \pm 28.51$ \\
\cline { 2 - 3 } & TC & 100.00 \\
\hline
\end{tabular}

a, b - means with different letters differed significantly at $\mathrm{P}<0.05$ (post-hoc Fisher LSD criterion) 
was found in cattle with genotype TT. The results of c.9421C>T showed cows homozygous for the $T$ allele had higher milk fat percentage than those of TC genotype while cows with genotype TT had no significant association with the milk protein content. Cows homozygous for the $C$ allele had the biggest impact on lactose percentage. Meanwhile, no significant association between two genotypes of $\mathrm{c}-10 \mathrm{C}>\mathrm{T}$ and fat, protein and lactose content was found.

TABLE 5. Effects of different SNP's of TLR4 gene on milk composition indicators

\begin{tabular}{l|l|l|l|l|l}
\hline SNP & Number of cows & Genotype & Fat, $\%$ & Protein, $\%$ & Lactose, $\%$ \\
\hline \multirow{2}{*}{ c.9421 C>T } & 43 & CC & $4.14 \pm 0.08$ & $3.43 \pm 0.04$ & $4.56 \pm 0.02$ \\
\cline { 2 - 6 } & 77 & TC & $4.24 \pm 0.08$ & $3.49 \pm 0.03$ & $4.54 \pm 0.03$ \\
\cline { 2 - 6 } & 32 & TT & $4.03 \pm 0.11$ & $3.45 \pm 0.06$ & $4.62 \pm 0.02$ \\
\hline \multirow{2}{*}{ c.2021 C>T } & 2 & CC & $4.69 \pm 0.33$ & $3.62 \pm 0.23$ & $4.67 \pm 0.06$ \\
\cline { 2 - 6 } & 145 & TC & $4.14 \pm 0.05$ & $3.46 \pm 0.02$ & $4.57 \pm 0.01$ \\
\cline { 2 - 6 } & 5 & TT & $4.65 \pm 0.23$ & $3.52 \pm 0.08$ & $4.48 \pm 0.04$ \\
\hline \multirow{2}{*}{ C. 10 C>T } & 151 & CC & $4.17 \pm 0.05$ & $3.46 \pm 0.02$ & $4.57 \pm 0.01$ \\
\cline { 2 - 6 } & 1 & TC & 3.97 & 3.5 & 4.66 \\
\hline
\end{tabular}

One-factor dispersion analysis (ANOVA) evaluated the influence of the TLR4 gene polymorphisms (c.2021C>T, Gen2 and c.9421C>T, Gen3) and the differences between different genotypes (Table 6). Six combination genotypes of the two TLR4 gene polymorphisms were detected in analysed Holstein cows. Most combined genotypes were associated with the fat content and SCC. Cows with the combined genotype of A6 produced respectively $0.65 \%$ and $0.58 \%$ more fat reach milk than those of the A5 and A3 genotypes $(P<0.05)$. Milk with the biggest lactose content was produced by cows of A5 group $(P<0.05)$. SCC mean of A5 combination genotype group had the lowest SCC by following $A 3$ and $A 4$ groups $(P<0.05)$. A1 genotype combination had the lowest SCC, but since only one cow had this genotype the results are questionable. Cows with A4 genotype combination showed the highest SCC.

TABLE 6. Combination effects of c.2021C>T and c.9421C>T polymorphisms (mean \pm SE)

\begin{tabular}{l|l|l|l|l|l}
\hline $\begin{array}{l}\text { Combination genotype } \\
\text { (Gen2_Gen3) }\end{array}$ & $\begin{array}{l}\text { Number } \\
\text { of cows }\end{array}$ & Fat, $\%$ & Protein, $\%$ & Lactose, $\%$ & SCC thousand/ml \\
\hline A1 (CC/TC) & 1 & 4.36 & 3.39 & 4.73 & 39 \\
\hline A2 (CC/TT) & 1 & 5.01 & 3.84 & 4.61 & 204 \\
\hline A3 (TC/CC) & 41 & $4.07 \pm 0.08^{\mathrm{a}}$ & $3.41 \pm 0.05$ & $4.57 \pm 0.02$ & $312.0 \pm 48.05^{\mathrm{a}}$ \\
\hline A4 (TC/TC) & 73 & $4.24 \pm 0.08$ & $3.49 \pm 0.03$ & $4.56 \pm 0.02$ & $366.8 \pm 49.02^{\mathrm{a}}$ \\
\hline A5 (TC/TT) & 31 & $4.00 \pm 0.10^{\mathrm{a}}$ & $3.44 \pm 0.06$ & $4.62 \pm 0.02^{\mathrm{a}}$ & $175.6 \pm 22.62^{\mathrm{b}}$ \\
\hline A6 (TT/CC) & 5 & $4.65 \pm 0.23^{\mathrm{b}}$ & $3.52 \pm 0.08$ & $4.48 \pm 0.04^{\mathrm{b}}$ & $289.2 \pm 84.55$ \\
\hline
\end{tabular}

a, b - means with different letters in each column differed significantly at $\mathrm{P}<0.05$ (post-hoc Fisher LSD criterion) 


\section{Discussion}

The bovine TLR4 gene is highly polymorphic (Wang et al., 2007; Mariotti et al., 2009) and some SNPs in the TLR4 gene have been associated with the somatic cell score (SCS) in cattle and milk traits (Sharma et al., 2006; Wang et al., 2007). Studies have reported that mutation in the TLR4 gene increases the susceptibility of cattle to mastitis (Sentitula et al., 2012). White et al. (2003) have identified several polymorphisms in the bovine TLR4 gene, many of which reportedly affect somatic cell count during mastitis. The study Razak et al. (2015) revealed that polymorphism is prevalent in the TLR4 gene and is significantly associated with mastitis in Holstein cross-bred cattle. El-Domany et al. (2019) study revealed TLR4 genes could partly be associated with an improvement in milk and reproductive performance in dairy cows which may lead to a brief and rigorous selection within dairy cows. The presence of these polymorphisms significantly affected the studied milk and reproductive parameters.

Our study was carried out to analyse three polymorphisms of the TLR4 gene and to determine their possible associations with SCC and milk composition traits in Holstein cows. Noori et al. (2013) showed the $T$ allele in c.9421C>T was associated with lower fat percentage and lower SCS when compared to allele C. Our results obtained frequency of allele $T$ dominated in c.9421C>T. Cows homozygous with $T$ allele produced milk with the lower fat content (4.03\%) but lactose content was the biggest (4.62\%) by following homozygous C allele although no reliable associations have been identified. Zhou et al. (2017) reported also that the phenotypic variation in milk traits of dairy cows in pasture-fed New Zealand (NZ) Holstein-Friesianx Jersey $(\mathrm{HF} \times J)$ cross dairy cows was attributed to TLR4 gene polymorphism. Two variants were observed, allele C was associated with higher milk yields and but lower milk fat percentage, whereas $T$ was associated with lower milk yields and higher fat and protein percentages. The study showed that SCS in cows with a TT genotype was significantly lower than that of the TC genotype $(P<0.05)$. The result indicated that the cattle with the TT genotype were more difficult to be infected with mastitis than the cattle with CC genotype and allele $T$ might be the beneficial allele for mastitis resistance. Sharma et al. (2015) demonstrated an association between the $C$ allele (the most frequent) with lower SCS in Holstein cows. Wang et al. (2007) found no significant association between the genotypes in C.9421C>T and SCS for Chinese Holstein cattle ( $P>0.05)$ but Gupta et al. (2015) determined the frequency of CC genotype was significantly higher $(P \leq 0.05)$ in healthy animals and indicated the association of CC genotype with resistance to mastitis in crossbred cows.

TLR4 c.2021C>T is a nonsynonymous SNP in exon 3 that corresponds to an amino acid change in the predicted transmembrane-cytoplasmic domain (Mariotti et al., 2009). This polymorphism is in locus rs8193069 of the TLR4 gene. Carvajal et al. (2013) found that for this SNP the most frequent variant in Holstein was the C allele (89\%) and allele T was found with low frequency (7\%) (Sharma et al., 2006) but our studies showed the more frequent T allele (51\%). Carvajal et al. (2013) also evaluated c.2021C>T of Chilean dairy cattle breeds associated with mastitis but no associations with SCS were evident. The results obtained in our studies also showed no significant association with SCS and the main milk composition indicators at this locus $(P>0.01)$ while Beecher et al. (2010) found c.2021C>T association $(P<0.05)$ with both milk protein and fat percentage $(P<0.01)$ in late lactation in Holstein-Friesian cows. The study of Peng et al. (2010) determined the homozygous genotype of c.2021C>T to be significantly associated with incidences of mastitis. Sharma et al. (2015) suggested that c.2021C>T may affect TLR4 signalling and lead to inadequate induction of immune response genes, and therefore that it may have been selected against by natural selection.

The result indicated that allele $\mathrm{C}$ was the predominant allele with a frequency of $99.3 \%$ in the c.-10C $>$ T. The genotypic effect on SCS and milk composition parameters were not significant. The cattle with the CC genotype showed bigger SCS in accordance with TC genotype. We can be predicted that $T$ allele may be could have a higher effect on SCS.

According to Sender et al. (2013) the best cumulative genotype does not identify individual genes, and animals are selected based on the estimated cumulative impact of multiple genes 
on resistance to mastitis. Mesquita et al. (2012) studied Brazilian Holsteins for TLR4 polymorphism indicated that animals with combined genotypes AACCCC, GGTCGG, and GACCGC presented the lowest SCS and have the potential to be applied as molecular markers for assisted animal selection to improve milk quality. Six combined genotypes of two TLR4 gene SNPs (c.9421C>T and c.2021C>T) were observed, though only one cow had a CC/TC and CC/TT combined genotype. Analysis of the combined genotypes revealed a significant correlation between the SCC and the genotype TC/TT (A5) $(P<0.05)$. There was also a significant association between this genotype and lactose content in milk $(P<0.05)$. Accordingly, this genotype $(T C / T T)$ could have the potential to be used as a genetic marker in the selection of animals with lower SCS and higher lactose percentage in milk.

\section{Conclusion}

The relationship between the bovine mastitis traits and the polymorphisms of TLR4 gene indicated that genotype TT of c.9421 C > T was related to mastitis resistance and allele $T$ might be the beneficial allele for mastitis resistance. The obtained results indicated that the selection of the TC/CC genotypes of the other two polymorphisms might contribute to a reduction of SCC in Lithuanian Holstein cows.

\section{Utjecaj polimorfizma gena TLR4 na kvalitetu i sastav mlijeka krava holstein pasmine u Litvi}

\section{Sažetak}

U okviru ove studije ispitivani su polimorfizmi c.9421C>T, c.2021C>T i c.-10C>T kravljeg gena TLR4 te njihova povezanost s brojem somatskih stanica i sastavom mlijeka. Uzorci krvi izuzeti su od ukupno 152 krave holstein pasmine u Litvi. Za tipizaciju polimorfizma gena TLR4 korištene su metode polimeraza lančane reakcije (PCR) i polimorfizam dužine restrikcijskih fragmenata (RFLP). Također su određivani broj somatskih stanica i odabrani parametri kemijskog sastava mlijeka (mast, protein, laktoza). Za određivanje utjecaja gena i statističkog značaja razlika među ispitivanim genotipovima korištena je jednosmjerna analiza varijance (ANOVA). Rezultati su pokazali da postoji statistička značajna povezanost između genotipa c.9421 C > T i broja somatskih stanica $(P<0,05)$. Jedinke genotipa TT imale su najniži broj somatskih stanica. Polimorfizmi c.2021C>T i c.-10C>T gena TLR4 nisu pokazali značajan utjecaj na otpornost prema mastitisu niti na sastav mlijeka. Analiza kombiniranih genotipova TC/CC polimorfizma c.2021C>T i c.9421C>T omogućili su utvrđivanje povezanosti SNP-ova s brojem somatskih stanica i s udjelom laktoze. Ovim istraživanjem je utvrđena značajna povezanost između broja somatskih stanica i polimorfizma c.9421C>T gena TLR4 u krava pasmine holstein u Litvi. Broj somatskih stanica u krava genotipa TT bio je značajno niži i ukazivao je na povezanost ovog genotipa s otpornošću na mastitis u c.9421C>T. Stoga se alel T može smatrati poželjnim za otpornost prema mastitisu.

\section{Ključne riječi: krave pasmine holstein, Litva, mlijeko, polimorfizmi jednog nukleotida, toll-like receptor 4}


1. Beecher, C., Daly, M., Childs, S., Berry, D., Magee, D., McCarthy, T., Giblin, L. (2010): Polymorphisms in bovine immune genes and their associations with somatic cell count and milk production in dairy cattle. BMC Genetics 11, 1-9. https://doi.org/10.1186/1471-2156-11-99

2. Burvenich, C., Van Merris, V., Mehrzad, J., Diez-Fraile, A., Duchateau, L. (2015): Severity of E. coli mastitis is mainly determined by cow factors. Veterinary Research 34, 521-564. https://doi.org/10.1051/vetres:2003023

3. Carvajal, A.M., Huircan, P., Lepori, A. (2013): Single nucleotide polymorphisms in immunity-related genes and their association with mastitis in Chilean dairy cattle. Genetics and Molecular Research 12, 2702-2711. https://doi.org/10.4238/2013.july.30.8

4. El-Domany, W.B., Radwan, W.A., Ateya, A.I., Ramadan, H.H., Marghani, B.H., Nasr, S.M. (2019): Genetic Polymorphisms in LTF/Eco RI and TLR4/Alu I loci as candidates for milk and reproductive performance assessment in Holstein cattle. Reproduction in Domestic Animals 54, 678-686. https://doi.org/10.1111/rda.13408

5. Gupta, P.H., Patel, N.A., Rank, D.N., Joshi, C.G. (2015): Genetic polymorphism of toll-like receptors 4 gene by polymerase chain reaction-restriction fragment length polymorphisms, polymerase chain reaction-single-strand conformational polymorphism to correlate with mastitic cows. Veterinary World 8, 615-620. https://doi.org/10.14202/vetworld.2015.615-620

6. Mariotti, M., Williams, J.L., Dunner, S., Valentini, A., Pariset, L. (2009): Polymorphisms within the toll-like receptor (TLR)-2, -4 and -6 genes in cattle. Diversity 1, 7-18. https://doi.org/10.3390/d1010007

7. Mesquita, A.Q., ERezende, C.S.M., Mesquita, A.J., Jardim, E.A., Kipnis, A.P. (2012): Associations of TLR4 polymorphisms with subclinical mastitis in Brasilian holsteins. Brazilian Journal of Microbiology 43, 692-697. https://doi.org/10.1590/s1517-83822012000200034

8. Noori, R., Mahdavi, A.H., Edriss, M.A., Rahmani, H.R., Talebi, M., Soltani-Ghombavani, M. (2013): Association of polymorphism in Exon 3 of toll-like receptor 4 gene with somatic cell score and milk production traits in Holstein dairy cows of Iran. South African Journal of Animal Science 43, 493-498.

https://doi.org/10.4314/sajas.v43i4.6

9. Ogorevc, J., Kunej, T., Razpet, A., Dovc, P. (2009): Database of cattle candidate genes and genetic markers for milk production and mastitis. Animal Genetics 40, 832-851. https://doi.org/10.1111/j.1365-2052.2009.01921.x

10. Opsal, M.A., Lien, S., Brenna-Hansen, S., Olsen, H.G., Vage, D.I. (2008): Association analysis of the constructed linkage maps covering TLR2 and TLR4 with clinical mastitis in Norwegian Red cattle. Journal of Animal Breeding and Genetics 125, 110-118. https://doi.org/10.1111/j.1439-0388.2007.00704.x

11. Peng, L., Jie, B., Zhang, X., Lixin, T., Shenglin, J., Wenrong, L., Mingjun, L. (2010): Association the mutation of 2021 locus of Toll-like receptor 4 gene (TLR4) exon III polymorphisms with somatic cell score in Xinjiang brown cattle. Journal of Agricultural Biotechnology 18, 1115-1122.
12. Razak, R., Hussain, I., Dar, P.A., Bashir, S.M., Bhat, S.A., Mir, M.R. (2015): Association of toll-like receptor 4 gene polymorphism with the severity of mastitis in crossbred dairy cattle. Applied Biological Research 17, 242-249. https://doi.org/10.5958/0974-4517.2015.00035.x

13. Ruegg P.L. (2003): Investigation of mastitis problems on farms. Veterinary Clinics of North America: Food Animal Practice 19, 47-73. https://doi.org/10.1016/s0749-0720(02)00078-6

14. Rupp, R., Boichard, D. (2015): Genetics of resistance to mastitis in dairy Cattle. Veterinary Research 34, 671-688. https://doi.org/10.1051/vetres:2003020

15. Sender, G., Korwin-Kossakowska, A., Pawlik, A., Hameed, K., Oprządek, J. (2013): Genetic basis of mastitis resistance in dairy cattle. Annals of Animal Science 13, 663-673. https://doi.org/10.2478/aoas-2013-0043

16. Sentitula, K.R., Yadav, B.R. (2012): Molecular analysis of TLR4 gene and its association with intra-mammary infection in Sahiwal cattle and Murah buffalo. Indian Journal of Biotechnology 11, 268-273.

17. Sharma, B.S., Abo- Ismail, M., Schenkel, F., You, Q., Verschoor, C., Pant, S., Karrow, N. (2015): Association of TLR4 polymorphisms with mycobacterium avium subspecies paratuberculosis infection status in Canadian holsteins. Animal Genetics 46, 560-565. https://doi.org/10.1111/age.12333

18. Sharma, B.S., Leyva, I., Schenkel, F., Karrow, N.A. (2006): Association of toll- like receptor 4 polymorphisms with somatic cell score and lactation persistency in holstein bulls. Journal of Dairy Science 89, 3626-3635. https://doi.org/10.3168/jds.s0022-0302(06)72402-x

19. Takeda, K., Kaisho, T., Akira, S. (2003): Toll-like receptors. Annual Review of Immunology 21, 335-376. https://doi.org/10.1146/annurev.immunol.21.120601.141126

20. Wang, X., Xu, S., Gao, X., Ren, H., Chen, J. (2007): Genetic polymorphism of TLR4 gene and correlation with mastitis in cattle. Journal of Genetics and Genomics 34, 406-412. https://doi.org/10.1016/s1673-8527(07)60044-7

21. White, S.N., Taylor, K.H., Abbey, C.A., Gill, C.A., Womack, J.E. (2003): Haplotype variation in bovine Toll-like receptor 4 and computational prediction of a positively selected ligand-binding domain. Proceeding of the National Academy Science of the United States of America 100, 10364-10369. https://doi.org/10.1073/pnas.1333957100

22. Yang, W., Zerbe, H., Petzl, W., Brunner, R.M., Günther, J., Draing, C., von Aulock, S., Schuberth, H.J., Seyfert, H.M. (2008): Bovine TLR2 and TLR4 properly transduce signals from Staphylococcus aureus and E. coli, but S. aureus fails to both activate NF-kappa B in mammary epithelial cells and to quickly induce TNF alpha and interleukin-8 (CXCL8) expression in the udder. Molecular Immunology 45, 13851397. https://doi.org/10.1016/j.molimm.2007.09.004

23. Zhou, H., Cheng, L., Gong, H., Byun, S.O., Edwards, G.R., Hickford, J.G.H. (2017): Variation in the Toll-like Receptor 4 (TLR4) gene affects milk traits in dairy cows. Journal of Dairy Research 84, 426-429. https://doi.org/10.1017/s0022029917000711 